Article

\title{
Assessment of Antioxidant and Anticancer Activities of Microgreen Alga Chlorella vulgaris and Its Blend with Different Vitamins
}

\author{
Ragaa A. Hamouda ${ }^{1,2, *}$, Amera Abd El Latif ${ }^{3}$, Ebtihal M. Elkaw ${ }^{2}$, Amenah S. Alotaibi ${ }^{4}$, Asma Massad Alenzi ${ }^{4}$ \\ and Hanafy A. Hamza ${ }^{2}$
}

check for

updates

Citation: Hamouda, R.A.; Abd El

Latif, A.; Elkaw, E.M.; Alotaibi, A.S.;

Alenzi, A.M.; Hamza, H.A.

Assessment of Antioxidant and

Anticancer Activities of Microgreen

Alga Chlorella vulgaris and Its Blend

with Different Vitamins. Molecules

2022, 27, 1602. https://doi.org/

10.3390/molecules 27051602

Academic Editors: Giorgos Markou and Leonel Pereira

Received: 16 January 2022

Accepted: 23 February 2022

Published: 28 February 2022

Publisher's Note: MDPI stays neutral with regard to jurisdictional claims in published maps and institutional affiliations.

Copyright: (C) 2022 by the authors. Licensee MDPI, Basel, Switzerland. This article is an open access article distributed under the terms and conditions of the Creative Commons Attribution (CC BY) license (https:// creativecommons.org/licenses/by/ $4.0 /)$.
1 Department of Biology, College of Sciences and Arts, Khulis, University of Jeddah, Jeddah 21959, Saudi Arabia

2 Department of Microbial Biotechnology, Genetic Engineering and Biotechnology Research Institute, University of Sadat City, Sadat 32897, Egypt; ebtihal.alkaw@gmail.com (E.M.E.); hanafi.hamza@gebri.usc.edu.eg (H.A.H.)

3 Department of Pharmacology, Faculty of Veterinary Medicine, Kafrelsheikh University, Kafrelsheikh 33516, Egypt; amirashehata12@yahoo.com

4 Biology Department, College of Sciences, Tabuk University, Tabuk 71491, Saudi Arabia; a_alotaibi@ut.edu.sa (A.S.A.); amalanazi@ut.edu.sa (A.M.A.)

* Correspondence: ragaahom@yahoo.com or ragaa.hamouda@gebri.usc.edu.eg

\begin{abstract}
There is a very vital antioxidant extracted from microgreen alga. Chlorella vulgaris has major advantages and requires high yield worldwide. Some microalgae require vitamins for their growth promotion. This study was held to determine the impact of different vitamins including Thiamine (B1), Riboflavin (B2), Pyridoxine (B6), and Ascorbic acid (c) at concentrations of 0.02, 0.04, 0.06 , and $0.08 \mathrm{mg} / \mathrm{L}$ of each. Each vitamin was added to the BG11 growth medium to determine the effect on growth, total carbohydrate, total protein, pigments content, antioxidant activities of Chlorella vulgaris. Moreover, antitumor effects of methanol extract of $C$. vulgaris without and with the supplement of thiamine against Human prostate cancer (PC-3), Hepatocellular carcinoma (HEPG-2), Colorectal carcinoma (HCT-116) and Epitheliod Carcinoma (Hela) was estimated in vitro. C. vulgaris supplemented with various vitamins showed a significant increase in biomass, pigment content, total protein, and total carbohydrates in comparison to the control. Thiamine was the best vitamin influencing as an antioxidant. C. vulgaris supplemented with thiamine had high antitumor effects in vitro. So, it's necessary to add vitamins to BG11 media for enhancement of the growth and metabolites.
\end{abstract}

Keywords: vitamins; Chlorella vulgaris; carbohydrate; antioxidant; antitumor

\section{Introduction}

Cancer lingers to be one of the principal sources of death in the Earth. Researchers sustained searching for harmless and further actual chemoprevention and care is required for the enhancement of the proficiency and to lower the cost for cancer treatments [1]. Microalgae have usually become part of the daily diet, specifically in East Asian countries; algae are an attractive research topic because of their active contents used to treat cancer [2]. Microalgae are usually used as an additive in food to enrich the nutrient of food and/or mend the health of beings due to phytochemical contents and bioactive molecules. The protein composition of microalgae is the chief goal for the untraditional source of protein [3]. Moreover, the microalgae which could synthesize vital amino acids to humans and animals compares beneficially with that of other sources of proteins [4]. In recent years, many researchers studied the assembly of extracellular antibiotic metabolites by marine algae, and the researchers discovered that a large number of antifungal agents are present in green microalgae extracts [5]. Ultimately, microalgae are almost an available supply of natural antioxidants due to their huge biodiversity, more varied than plants. 
They enclose various biologically vigorous composites that are consumed as a source of food, feed, and medicine [6]. Microalgae are offered as a replacement to the molecular pharming system. [7]. Natural antioxidants exposed greater antioxidant productivity than synthetic antioxidants [8] Algae represent a sources of natural antioxidant compounds such as carotenoid, vitamins, phenolic compounds, and phycobilins, that have different applications in various areas such as pharmaceutical, nutraceutical, medicine and food industries [9]. Microalgae are an important source of pharmacologically vigorous metabolites with antineoplastic, antitumor, antibacterial, antifungal, and antiviral activities [6]. Chlorella is considered one of the oldest microorganisms on earth due to its sphere form and very stable cell wall. Chlorella sp. is a type of unicellular eukaryotic green microalga [10]. Taiwan is one of the major countries to produce Chlorella-related productions. The world annual sales of Chlorella sp. are more than US\$ 38 billion [11]. C. vulgaris which related to the marine microalgae have been found to contain the huge number of highly nutritious effective substances which are valuable to the human body and exert various biological effects such as pigments, proteins, unsaturated fatty acids, squalene, polysaccharides, etc. [12]. It is widely used in popular food additives and it is considered a potential source for healthy food in many countries and is effective in improving overall health and well-being $[13,14]$. It is rich in proteins, which involve all essential amino acids requisite for human growth and wellbeing [15]. It contains chlorophyll- $a$ and $b$, and primary carotenoids, such as lutein and $\beta$-carotene. Moreover, it is considered a functional whole food with lower cholesterol due to providing large amounts of dietary fibers, nucleic acids, carbohydrates, vitamins, fatty acids, minerals, and chlorophyll [16]. Chlorella vulgaris supplementation has been reported to have certain promising physiological properties, specifically protecting against the immunosuppressive effect of stress and gastric ulcer formation [17]. Furthermore, it showed anti-inflammatory, immune-modulatory hepatoprotective, anti-diabetic, antihypertensive, antioxidative and hypocholesterolemic, and anticancer or antitumor activities [18-21]. Vitamins are a chemically unrelated organic compound that cannot be synthesized in adequate quantities by beings and therefore must be blend to the diet. Nine vitamins (B complex and non-complex (vitamin C) are classified as water-soluble, whereas four vitamins (vitamins A, D, K, and E) are classified as fat-soluble. They perform various roles such as cofactor of various enzymes, the regulator of mineral metabolism and antioxidant activities, etc.; also concerned in the general metabolism of the organism. Many research illustrated algal species that demand diverse combinations of three B vitamins: vitamin B1 (thiamine), vitamin B12 (cobalamin), and vitaminB7 (biotin). Cruz-López and Maske [22] reported that the maximum growth rate of Lingulodinium polyedrum (dinoflagellate) was obtained when acquiring B1 and B12 vitamins from the associated bacterial community. Algae were incubated with vitamins showed a growth rate increase with higher vitamins concentrations, meanwhile algal cell volume decrease [23]. There are very few studies related to the effects of various vitamins supplementations on algal growth and productivity. This study was aimed to compare the effects of different vitamins added to the BG11 growth medium on the Chlorella vulgaris growth, Chlorophyll- $a$, Chlorophyll $b$, carotenoid, protein, carbohydrates contents, and antioxidant activity. In addition, the antitumor effect of $C$. vulgaris and C. vulgaris blend with thiamine at different concentrations was determined.

\section{Results}

The results showed the effect of different vitamins supplementations (Thiamine (B1), Riboflavin (B2), Pyridoxine (B6), Ascorbic acid (C)), used at four different concentrations $(0.02,0.04,0.06$ and $0.08 \mu \mathrm{g} / \mathrm{L})$ on the biomass production (Optical density), total photosynthetic pigments contents, antioxidant (DPPH) activity, total protein and carbohydrate contents of C. vulgaris during 18 days of cultivation.

\subsection{The Effect of Vitamins Supplementations on C. vulgaris Biomass Production}

Results obtained in Figure 1a show the optical density of C. vulgaris supplemented with different concentrations of Pyridoxal (vitamin B6) at $660 \mathrm{~nm}$. The growth of C. vulgaris 
was increased within three days of inoculation with all tested concentrations of Pyridoxal (vitamin B6). The best concentrations were $0.08 \mu \mathrm{g} / \mathrm{L}$ of Pyridoxal followed by $0.06 \mu \mathrm{g} / \mathrm{L}$. Meanwhile the control C. vulgaris (without vitamin supplementation) produced the least amount of biomass compared with the other concentrations of Pyridoxal. Figure $1 \mathrm{~b}$ demonstrated the effect of different concentrations of Ascorbic acid (vitamin C) on C. vulgaris growth within 18 days of incubation. Moderate growth was obtained at the first three days of incubation. The maximum growth was obtained with the highest concentrations $(0.08 \mu \mathrm{g} / \mathrm{L})$ until the 14 days of incubations, but after 14 days the elevations of growth were obtained by the following Ascorbic acid (vitamin C) concentrations 0.02, 0.04, 0.08, and $0.06 \mu \mathrm{g} / \mathrm{L}$ and control, respectively. The elevation of C. vulgaris growth was observed in the first three days of incubation with all the tested concentrations of Thiamine. From three to seven days the stationary phase of $C$. vulgaris occurred with $0.06 \mu \mathrm{g} / \mathrm{L}$ of Thiamine. Moderate elevations of $C$. vulgaris growth occurred with the following concentrations, 0.02 , 0.04 , and $0.08 \mu \mathrm{g} / \mathrm{L}$ of Thiamine at 3 to 7 days of incubations, meanwhile, the elevations of growth were obtained after seven days of $C$. vulgaris incubation until 16th day of incubation with $0.08,0.08 \mu \mathrm{g} / \mathrm{L}$ and control, respectively, Figure 1c. BG 11 media when supplemented with riboflavin (vitamin B2), the growth of C. vulgaris was increased, Figure $1 \mathrm{~d}$. High elevations of $C$. vulgaris growth were obtained in the first three days of cultivations with all concentrations of riboflavin. The $0.02 \mu \mathrm{g} / \mathrm{L}$ was the best concentration of riboflavin that caused high elevation of growth at 10 to 20 days followed by $0.08,0.04$ and $0.06 \mu \mathrm{g} / \mathrm{L}$, respectively, in compared with control.

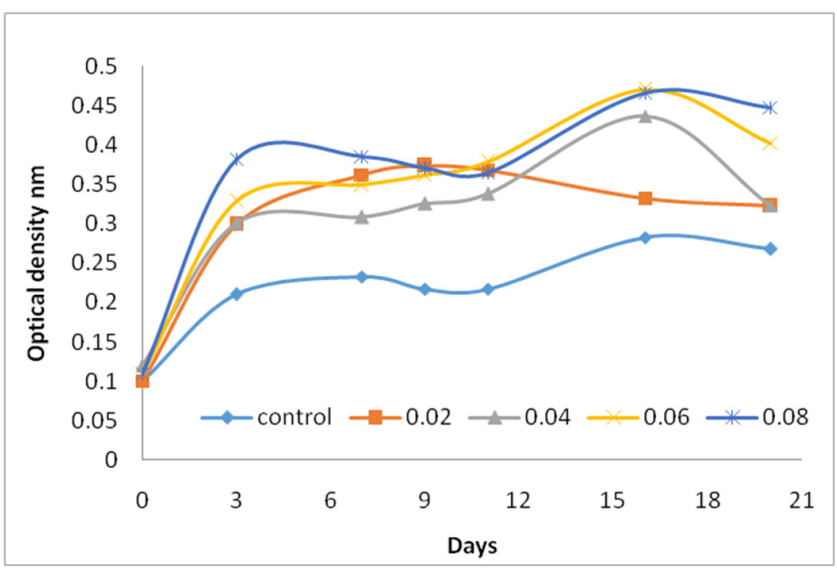

(a)

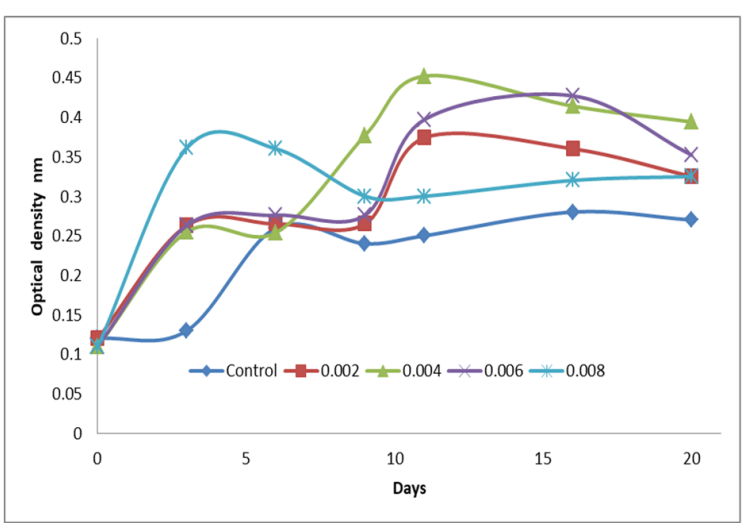

(c)

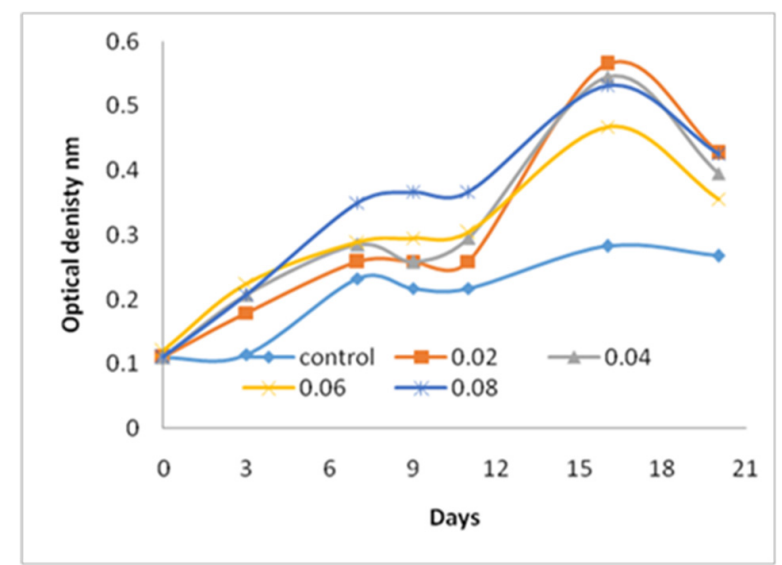

(b)

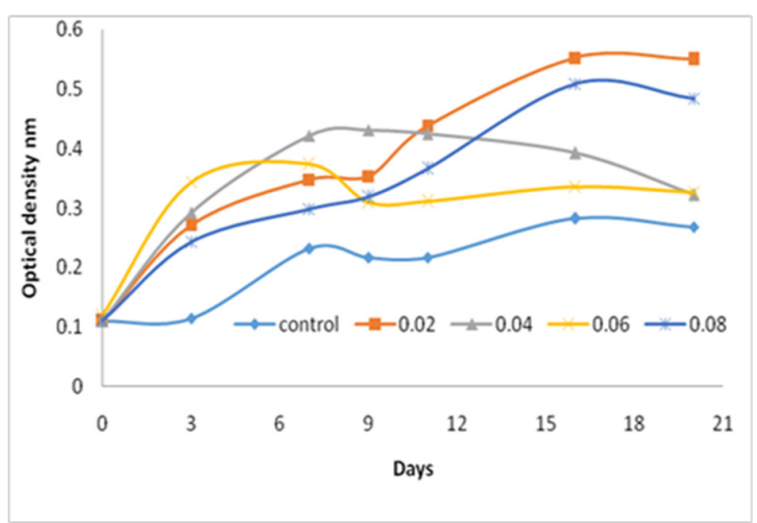

(d)

Figure 1. Effect of different concentrations of Pyridoxal (vitamin B6) (a), Ascorbic acids (vitamin C) (b), Thiamine (vitamin B1) (c), and riboflavin (vitamin B2) (d) on C. vulgaris growth measured by Optical density (nm). 


\subsection{The Effect of Vitamins Supplementations on the Photosynthetic Pigments of C. vulgaris}

The present results indicated that there were significant differences in chlorophyll-a, chlorophyll-b and carotenoid pigments at the different sampling days except for chlorophyll-b in the control group showed non-significant differences. Moreover, significant differences were observed in the pigments contents for different concentrations of Pyridoxal at different experimental days being at range from $0.19(0.08 \mu \mathrm{g} / \mathrm{L}$ concentrate after 3 days $)$ to 3.06 (control group after 11 days) for chlorophyll-a and from $0.84(0.08 \mu \mathrm{g} / \mathrm{L}$ concentrate after 3 days) to $6.42(0.02 \mu \mathrm{g} / \mathrm{L}$ concentrate after 16 days $)$ for chlorophyll-b, while they varied from $5.20(0.08 \mu \mathrm{g} / \mathrm{L}$ concentrate after 3 days $)$ to 24.12 ( $0.02 \mu \mathrm{g} / \mathrm{L}$ concentrate after 11 days $)$ for Carotenoid (Table 1).

It appears that the sampling time had no significant influence on chlorophyll-a content at 0.06 and 0.08 concentrations of ascorbic acid; chlorophyll-b for the control group and 0.06 ascorbic acid concentration; Carotenoid for 0.06 and $0.08 \mu \mathrm{g} / \mathrm{L}$ ascorbic acid concentrations. In contrast, a significant effect of sampling time was observed on all pigments at 0.02 and $0.04 \mu \mathrm{g} / \mathrm{L}$ ascorbic acid concentration; chlorophyll-b at $0.08 \mu \mathrm{g} / \mathrm{L}$ concentration; chlorophyll-b and Carotenoid for the control group. Furthermore, significant differences appeared in the pigments' contents for different concentrations of ascorbic acid at different experimental days varied from 1.10 to 5.56 for chlorophyll-a, from 0.36 to 4.56 for chlorophyll-b, and from 5.36 to 22.91 for Carotenoid as presented in Table 2.

Table 3 demonstrates the effect of different concentrations of thiamine and days of incbation on the pigments content of $C$. vulgaris. As presented in Table 1, no-significant effects of sampling time were observed on chlorophyll-b content for control group, 0.04 and $0.08 \mu \mathrm{g} / \mathrm{L}$ Thiamine concentrations; Carotenoid at 0.02 and $0.06 \mu \mathrm{g} / \mathrm{L}$ concentrations, while significant differences were recorded for chlorophyll-a content at different concentrations; chlorophyll- $b$ at $0.02,0.06 \mu \mathrm{g} / \mathrm{L}$ concentrations; Carotenoid at 0.04 and $0.08 \mu \mathrm{g} / \mathrm{L}$ concentrations. In addition, significant differences were observed in the pigments' contents for different concentrations of Thiamine at different experimental days except 0.02 and $0.04 \mu \mathrm{g} / \mathrm{L}$ concentrations after 3 and 16 days; concentration $0.06 \mu \mathrm{g} / \mathrm{L}$ after 11 and 16 days. Minimum estimates were $0.03,0.08$, and $3.77 \mu \mathrm{g} / \mathrm{L}$, while the maximum estimates were $4.05,4.26$, and $29.27 \mu \mathrm{g} / \mathrm{L}$ for chlorophyll-a, chlorophyll-b, and carotenoids, respectively.

Results in Table 4 indicate that there was a significant effect of sampling time from day 3 to day 20 post the beginning of the experiment on chlorophyll-a, chlorophyll-b, and Carotenoid pigments except for chlorophyll-b in the control group showed non-significant differences. In addition, non-significant differences were observed in the pigments' contents for different concentrations of riboflavin at different experimental days except control group at different days, $0.02 \mu \mathrm{g} / \mathrm{L}$ concentration after 3,11 , and 20 days, 0.06 after 3 and 16 days and $0.08 \mu \mathrm{g} / \mathrm{L}$ concentrations after 9 and 16 days. Minimum estimates were $0.04,0.40$, and $0.04 \mu \mathrm{g} / \mathrm{L}$, while the maximum estimates were $5.30,4.48$, and 17.48 for chlorophyll-a, chlorophyll- $b$ and carotenoids, respectively.

\subsection{Effect of Different Concentrations of the Tested Vitamins on Carbohydrate and Proteins Contents of $C$. vulgaris}

Results in Table 5 indicated that there were highly significant differences in carbohydrates and proteins contents under the effect of the different concentrations of the tested vitamins. The best concentration of vitamins for enhancement of carbohydrate content of C. vulgaris was $0.08 \mu \mathrm{g} / \mathrm{L}$ for all the tested vitamins. Meanwhile, the best concentration was different among vitamins concerning their effect on proteins content as the best concentration was $0.08 \mu \mathrm{g} / \mathrm{L}$ Thiamine, 0.06 Riboflavin, and Pyridoxal. Meanwhile, Ascorbic acids diminished the protein content of $C$. vulgaris. concerning protein values, minimum values were coupled with 0.04 concentration for all vitamins, while the maximum values were observed at 0.08 concentration for Thiamine, 0.02 for Ascorbic acid; 0.06 for Riboflavin and Pyridoxal. 
Table 1. Pigments produced by C. vulgaris supplemented with various concentrations of Pyridoxal (vitamin B6).

\begin{tabular}{|c|c|c|c|c|c|c|c|c|c|}
\hline \multirow{2}{*}{\multicolumn{2}{|c|}{ Vitamins Conc. $\mu \mathrm{g} / \mathrm{L}$}} & \multirow{2}{*}{ Pigments } & \multicolumn{7}{|c|}{ Days } \\
\hline & & & 3 & 7 & 9 & 11 & 16 & 20 & $p$-Value \\
\hline \multirow{3}{*}{ Control } & & Chl a & $1.17 \pm 0.06 \mathrm{bB}$ & $3.12 \pm 0.02 \mathrm{aB}$ & $1.53 \pm 0.08 \mathrm{bB}$ & $3.06 \pm 0.49 \mathrm{aB}$ & $1.81 \pm 0.05 \mathrm{bB}$ & $1.79 \pm 0.07 \mathrm{bB}$ & $* *$ \\
\hline & & Chl b & $1.04 \pm 0.05 \mathrm{~B}$ & $1.28 \pm 0.09 \mathrm{C}$ & $1.26 \pm 0.06 \mathrm{~B}$ & $1.12 \pm 0.35 \mathrm{~B}$ & $1.61 \pm 0.14 \mathrm{~B}$ & $1.23 \pm 0.04 \mathrm{~B}$ & NS \\
\hline & $p$-Value & Carotenoid & $\underset{* * *}{10.65 \pm 1.50 \mathrm{cA}}$ & $\underset{* * *}{5.36 \pm 0.29 \mathrm{dA}}$ & $10.88 \pm \underset{* * *}{0.88} \mathrm{cbA}$ & $17.48 \underset{* * *}{ \pm 0.83} \mathrm{aA}$ & $\underset{* * *}{0.29} \mathrm{aA}$ & $\underset{* * *}{0.83} \mathrm{bA}$ & $* *$ \\
\hline \multirow{3}{*}{0.02} & & Chl a & $2.25 \pm 0.48 \mathrm{abB}$ & $1.63 \pm 0.20 \mathrm{bB}$ & $1.55 \pm 0.03 \mathrm{bB}$ & $2.83 \pm 0.38 \mathrm{aB}$ & $2.03 \pm 0.27 \mathrm{abB}$ & $2.24 \pm 0.09 \mathrm{abB}$ & * \\
\hline & & Chl b & $0.93 \pm 0.17 \mathrm{bB}$ & $1.96 \pm 0.26 \mathrm{bB}$ & $2.10 \pm 0.04 \mathrm{bB}$ & $3.63 \pm 0.43 \mathrm{bB}$ & $6.42 \pm 1.69 \mathrm{aB}$ & $3.50 \pm 0.43 \mathrm{bB}$ & $* *$ \\
\hline & $p$-Value & Carotenoid & $10.50 \pm \underset{* * *}{1.24} \mathrm{bA}$ & $\underset{* * *}{7.75 \pm 0.98 \mathrm{bA}}$ & $12.68 \underset{* * *}{ \pm 0.34} \mathrm{bA}$ & $24.12 \pm \underset{* * *}{2.73} \mathrm{aA}$ & $19.21 \pm \underset{* * *}{2.96} \mathrm{abA}$ & $12.42 \pm \underset{* * *}{1.85} \mathrm{bA}$ & $* * *$ \\
\hline \multirow{3}{*}{0.04} & & Chl a & $0.54 \pm 0.14 \mathrm{cB}$ & $1.30 \pm 0.04 \mathrm{cbB}$ & $1.24 \pm 0.24 \mathrm{cbB}$ & $2.57 \pm 0.68 \mathrm{aB}$ & $2.85 \pm 0.36 \mathrm{abB}$ & $2.27 \pm 0.59 \mathrm{abB}$ & $* *$ \\
\hline & & Chl b & $0.92 \pm 0.37 \mathrm{cB}$ & $1.45 \pm 0.28 \mathrm{cbB}$ & $1.43 \pm 0.009 \mathrm{cbB}$ & $2.81 \pm 0.47 \mathrm{aB}$ & $2.32 \pm 0.18 \mathrm{abB}$ & $1.38 \pm 0.50 \mathrm{cbB}$ & * \\
\hline & \multirow{2}{*}{$p$-Value } & Carotenoid & $\underset{* * *}{9.19 \pm 1.64 \mathrm{bA}}$ & $10.24 \underset{* * *}{ \pm} 1.72 \mathrm{bA}$ & $\underset{* * *}{10.32 \pm 0.95 \mathrm{bA}}$ & $\underset{* * *}{19.60 \pm 1.50} \mathrm{aA}$ & $\underset{* * *}{15.42 \pm 1.10 \mathrm{aA}}$ & $\underset{* * *}{17.89} \underset{2.32}{\mathrm{aA}}$ & $* * *$ \\
\hline \multirow{3}{*}{0.06} & & Chl a & $0.28 \pm 0.03 \mathrm{dC}$ & $1.03 \pm 0.07 \mathrm{cdB}$ & $1.55 \pm 0.08 \mathrm{cbB}$ & $2.58 \pm 0.55 \mathrm{aB}$ & $2.18 \pm 0.33 \mathrm{abB}$ & $1.81 \pm 0.14 \mathrm{abcB}$ & $* *$ \\
\hline & \multirow[b]{2}{*}{$p$-Value } & Chl b & $2.06 \pm 0.63 \mathrm{abB}$ & $1.46 \pm 0.10 \mathrm{bB}$ & $2.23 \pm 0.17 \mathrm{abB}$ & $2.54 \pm 0.63 \mathrm{abB}$ & $2.92 \pm 0.122 \mathrm{aB}$ & $2.51 \pm 0.35 \mathrm{abB}$ & * \\
\hline & & Carotenoid & $\underset{* * *}{6.80 \pm 0.47 \mathrm{bA}}$ & $12.31 \pm \underset{* * *}{0.54} \mathrm{abA}$ & $12.03 \pm \underset{* * *}{0.59} \mathrm{abA}$ & $\underset{* * *}{12.10 \pm \underset{* * 18}{4.18} \mathrm{abA}}$ & $\underset{* * *}{16.71} \underset{*}{1.39} \mathrm{aA}$ & $15.43 \pm \underset{* * *}{0.79} \mathrm{aA}$ & $* * *$ \\
\hline \multirow{2}{*}{0.08} & & Chl a & $0.19 \pm 0.06 \mathrm{cB}$ & $2.58 \pm 0.43 \mathrm{aB}$ & $1.58 \pm 0.62 \mathrm{abB}$ & $1.41 \pm 0.31 \mathrm{bB}$ & $1.81 \pm 0.60 \mathrm{abB}$ & $1.64 \pm 0.08 \mathrm{abB}$ & $* * *$ \\
\hline & $p$-Value & Carotenoid & $\underset{* * *}{5.20 \pm 1.55 \mathrm{bA}}$ & $9.68 \pm \underset{* * *}{1.53} \mathrm{abA}$ & $\underset{* * *}{11.25 \pm 1.46} \mathrm{abA}$ & $\underset{* * *}{16.85 \pm}+4.50 \mathrm{aA}$ & $\underset{* * *}{11.28} \pm \underset{ }{2.20} \mathrm{abA}$ & $9.32 \pm \underset{* * *}{1.30} \mathrm{abA}$ & * \\
\hline
\end{tabular}


Table 2. Pigments produced by C. vulgaris supplemented with various concentrations of Ascorbic acid (Vitamin C).

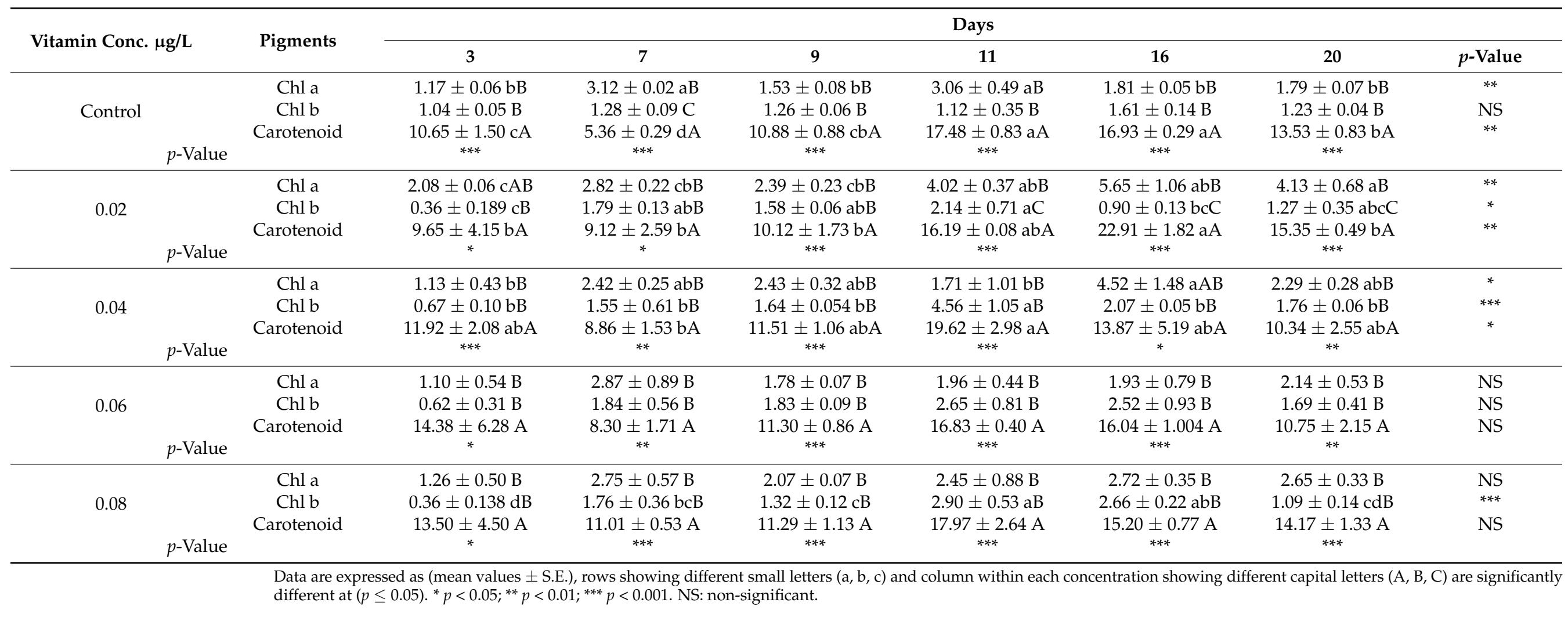


Table 3. Pigments produced by C. vulgaris supplemented with various concentrations of Thiamine (vitamin B1).

\begin{tabular}{|c|c|c|c|c|c|c|c|c|}
\hline \multirow{2}{*}{ Vitamin Conc. $\mu \mathrm{g} / \mathrm{L}$} & \multirow{2}{*}{ Pigments } & \multicolumn{7}{|c|}{ Days } \\
\hline & & 3 & 7 & 9 & 11 & 16 & 20 & $p$-Value \\
\hline \multirow[b]{2}{*}{ Control } & Chl $a$ & $1.17 \pm 0.06 \mathrm{bB}$ & $3.12 \pm 0.02 \mathrm{aB}$ & $1.53 \pm 0.08 \mathrm{bB}$ & $3.06 \pm 0.49 \mathrm{aB}$ & $1.81 \pm 0.05 \mathrm{bB}$ & $1.79 \pm 0.07 \mathrm{bB}$ & $* *$ \\
\hline & Chl b & $1.04 \pm 0.05 \mathrm{~B}$ & $1.28 \pm 0.09 \mathrm{C}$ & $1.26 \pm 0.06 \mathrm{~B}$ & $1.12 \pm 0.35 \mathrm{~B}$ & $1.61 \pm 0.14 \mathrm{~B}$ & $1.23 \pm 0.04 \mathrm{~B}$ & NS \\
\hline \multirow[b]{2}{*}{$p$-Value } & Carotenoid & $10.65 \pm 1.50 \mathrm{cA}$ & $5.36 \pm 0.29 \mathrm{dA}$ & $10.88 \pm 0.88 \mathrm{cbA}$ & $17.48 \pm 0.83 \mathrm{aA}$ & $16.93 \pm 0.29 \mathrm{aA}$ & $13.53 \pm 0.83 \mathrm{bA}$ & $* *$ \\
\hline & & $* * *$ & $* * *$ & $* * *$ & $* * *$ & $* * *$ & $* * *$ & \\
\hline \multirow{4}{*}{0.02} & Chl a & $0.63 \pm 0.21 \mathrm{~d}$ & $2.26 \pm 0.34 \mathrm{cbB}$ & $1.28 \pm 0.19 \mathrm{cdB}$ & $4.28 \pm 0.56 \mathrm{aB}$ & $3.41 \pm 0.90 \mathrm{ab}$ & $3.26 \pm 0.32 \mathrm{abB}$ & $* *$ \\
\hline & Chl b & $0.08 \pm 0.13 \mathrm{~d}$ & $2.17 \pm 0.42 \mathrm{cbB}$ & $1.51 \pm 0.07 \mathrm{cB}$ & $4.26 \pm 0.78 \mathrm{aB}$ & $3.47 \pm 0.58 \mathrm{ab}$ & $2.20 \pm 0.18 \mathrm{bcB}$ & $*$ \\
\hline & Carotenoid & $9.05 \pm 5.32$ & $8.22 \pm 1.51 \mathrm{~A}$ & $14.68 \pm 0.74 \mathrm{~A}$ & $19.001 \pm 3.58 \mathrm{~A}$ & $9.48 \pm 4.53$ & $12.36 \pm 0.66 \mathrm{~A}$ & NS \\
\hline & & NS & $* * *$ & $* * *$ & $* * *$ & NS & $* * *$ & \\
\hline \multirow[b]{4}{*}{$p$-Value } & Chl a & $0.42 \pm 0.37 \mathrm{~b}$ & $2.29 \pm 0.03 \mathrm{abB}$ & $2.02 \pm 0.035 \mathrm{abB}$ & $3.64 \pm 1.58 \mathrm{aB}$ & $4.01 \pm 0.43 \mathrm{a}$ & $4.05 \pm 0.63 \mathrm{aB}$ & $* *$ \\
\hline & Chl b & $1.24 \pm 0.89$ & $2.50 \pm 0.31 \mathrm{~B}$ & $1.54 \pm 0.09 \mathrm{~B}$ & $2.85 \pm 0.61 \mathrm{~B}$ & $3.07 \pm 0.60$ & $1.54 \pm 0.27 \mathrm{C}$ & NS \\
\hline & Carotenoid & $3.77 \pm 2.18 b$ & $7.30 \pm 0.59 \mathrm{abA}$ & $9.80 \pm 1.78 \mathrm{abA}$ & $15.60 \pm 2.49 \mathrm{aA}$ & $8.94 \pm 4.84 \mathrm{ab}$ & $7.56 \pm 0.78 \mathrm{abA}$ & $* *$ \\
\hline & & NS & $* *$ & $* *$ & $* * *$ & NS & $* *$ & \\
\hline \multirow{3}{*}{$p$-Value } & Chl a & $0.76 \pm 0.27 \mathrm{bB}$ & $2.42 \pm 0.34 \mathrm{aB}$ & $2.02 \pm 0.039 \mathrm{abB}$ & $2.68 \pm 0.57 \mathrm{a}$ & $2.05 \pm 0.78 \mathrm{ab}$ & $2.15 \pm 0.11 \mathrm{abB}$ & $* *$ \\
\hline & Chl b & $0.93 \pm 0.62 \mathrm{cB}$ & $1.93 \pm 0.23 \mathrm{cbB}$ & $2.08 \pm 0.14 \mathrm{cbB}$ & $3.85 \pm 0.41 \mathrm{a}$ & $3.09 \pm 0.60 \mathrm{ab}$ & $2.23 \pm 0.29 \mathrm{bcB}$ & $* *$ \\
\hline & Carotenoid & $10.54 \pm 2.00 \mathrm{~A}$ & $10.96 \pm 1.77 \mathrm{~A}$ & $8.57 \pm 1.23 \mathrm{~A}$ & $7.48 \pm 4.09$ & $4.66 \pm 0.92$ & $8.86 \pm 1.44 \mathrm{~A}$ & NS \\
\hline \multirow{3}{*}{0.08} & Chl a & $0.036 \pm 0.15 c$ & $3.47 \pm 0.172 \mathrm{aB}$ & $1.98 \pm 0.109 \mathrm{bB}$ & $1.78 \pm 0.400 \mathrm{bB}$ & $1.93 \pm 0.50 \mathrm{bB}$ & $1.66 \pm 0.46 \mathrm{bB}$ & $* * *$ \\
\hline & Chl b & $2.23 \pm 0.96$ & $1.74 \pm 0.08 \mathrm{~B}$ & $2.10 \pm 0.20 \mathrm{~B}$ & $2.92 \pm 0.18 \mathrm{~B}$ & $2.24 \pm 0.39 \mathrm{~B}$ & $2.14 \pm 0.52 \mathrm{~B}$ & NS \\
\hline & Carotenoid & $5.34 \pm 2.83 \mathrm{~b}$ & $8.97 \pm \underset{* *}{1.001 \mathrm{bA}}$ & $10.83 \pm \underset{*}{3.05} \mathrm{bA}$ & $29.27 \underset{* * *}{2} .40 \mathrm{aA}$ & $12.43_{* * *}^{ \pm} 3.02 \mathrm{bA}$ & $8.11 \pm \underset{* * *}{0.47 \mathrm{bA}}$ & $* * *$ \\
\hline
\end{tabular}

Data are expressed as (mean values \pm S.E.), rows showing different small letters (a, b, c) and column within each concentration showing different capital letters (A, B, C) are significantly different at $(p \leq 0.05) .{ }^{*} p<0.05 ;{ }^{* *} p<0.01 ;{ }^{* * *} p<0.001$. NS: non-significant. 
Table 4. Pigments produced by C. vulgaris supplemented with various concentrations of riboflavin (vitamin B2).

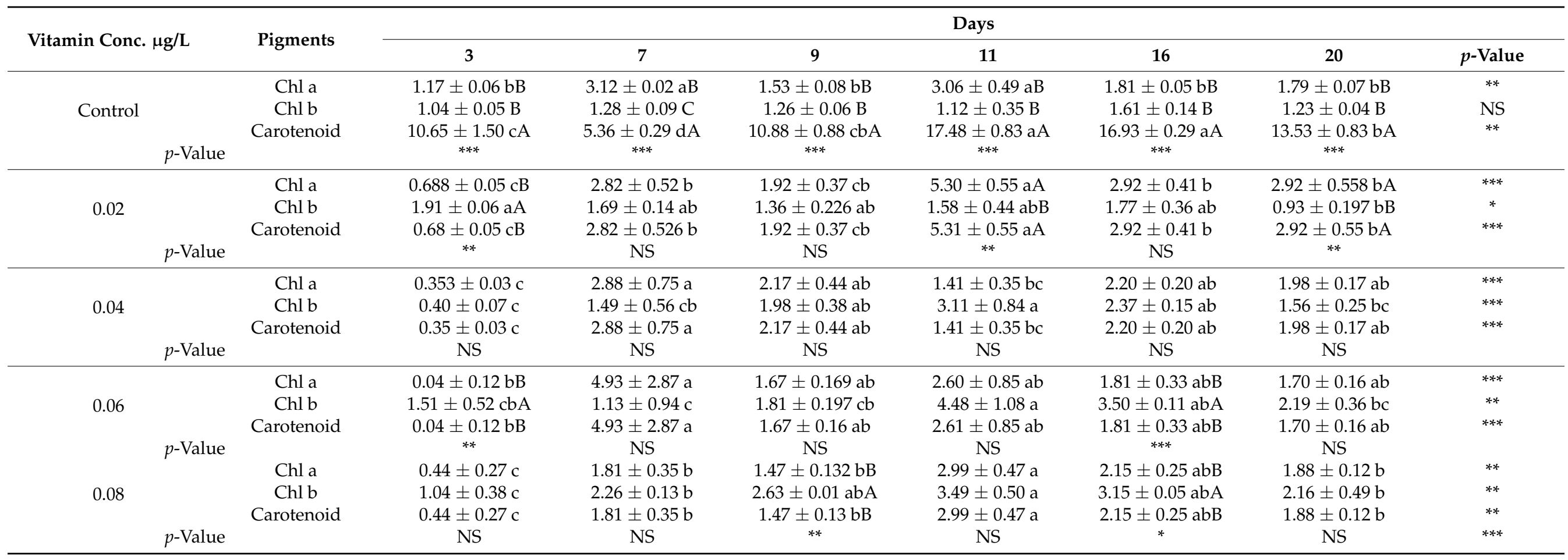

Data are expressed as (mean values \pm S.E.), rows showing different small letters $(\mathrm{a}, \mathrm{b}, \mathrm{c})$ and column within each concentration showing different capital letters (A, B, C) are significantly different at $(p<0.05) .{ }^{*} p<0.05 ;{ }^{* *} p<0.01 ;{ }^{* * *} p<0.001$. NS: non-significant. 
Table 5. Effect of different concentrations of the tested vitamins on carbohydrate and proteins contents of C. vulgaris.

\begin{tabular}{|c|c|c|c|}
\hline Vitamin & Concentration $(\mu \mathrm{g} / \mathrm{L})$ & Carbohydrate (mg/g) & Proteins (mg/g) \\
\hline \multirow[t]{3}{*}{ Control } & 0 & $149.97 \pm 0.88$ & $50.676 \pm 0.864$ \\
\hline & 0.02 & $165.30 \pm 0.57 c$ & $55.088 \pm 1.452 \mathrm{~b}$ \\
\hline & 0.04 & $147.64 \pm 1.76 \mathrm{~d}$ & $48.552 \pm 0.589 c$ \\
\hline \multirow{3}{*}{ Thiamine } & 0.06 & $195.30 \pm 0.57 b$ & $52.637 \pm 2.536 \mathrm{cb}$ \\
\hline & 0.08 & $250.30 \pm 0.57 \mathrm{a}$ & $64.402 \pm 0.712 \mathrm{a}$ \\
\hline & $p$-Value & $* * *$ & $* * *$ \\
\hline \multirow{5}{*}{ Riboflavin } & 0.02 & $194.64 \pm 0.33 c$ & $49.533 \pm 0.993 b$ \\
\hline & 0.04 & $171.30 \pm 0.57 \mathrm{~d}$ & $46.755 \pm 1.337 \mathrm{~b}$ \\
\hline & 0.06 & $207.97 \pm 1.45 b$ & $63.912 \pm 0.993 \mathrm{a}$ \\
\hline & 0.08 & $215.97 \pm 1.20 \mathrm{a}$ & $47.572 \pm 1.609 \mathrm{~b}$ \\
\hline & $p$-Value & $* * *$ & $* * *$ \\
\hline \multirow{5}{*}{ Asorbic acid } & 0.02 & $206.30 \pm 1.15 c$ & $63.748 \pm 0.432 \mathrm{a}$ \\
\hline & 0.04 & $244.64 \pm 0.33 b$ & $48.552 \pm 0.589 \mathrm{~d}$ \\
\hline & 0.06 & $206.64 \pm 0.88 c$ & $50.350 \pm 0.283 c$ \\
\hline & 0.08 & $284.64 \pm 0.33 \mathrm{a}$ & $53.781 \pm 0.748 \mathrm{~b}$ \\
\hline & $p$-Value & $* * *$ & $* * *$ \\
\hline \multirow{5}{*}{ Pyridoxal } & 0.02 & $244.64 \pm 0.33 c$ & $45.774 \pm 1.452 \mathrm{~b}$ \\
\hline & 0.04 & $224.64 \pm 0.33 \mathrm{~d}$ & $43.650 \pm 0.589 b$ \\
\hline & 0.06 & $345.30 \pm 0.57 b$ & $56.069 \pm 1.884 \mathrm{a}$ \\
\hline & 0.08 & $348.97 \pm 1.85 \mathrm{a}$ & $45.284 \pm 2.305 b$ \\
\hline & $p$-Value & $* * *$ & $* * *$ \\
\hline
\end{tabular}

Data are expressed as (mean values \pm S.E.), column showing different small letters $(a, b, c)$ are significantly different at $(p \leq 0.05)$. ${ }^{* * *} p<0.001$.

\subsection{Antioxidant Activities of C. vulgaris and C. vulgaris Supplemented with Different} Concentrations of the Tested Vitamins

DPPH (Antioxidant assay) 1,1-Diphenyl-2-picryl-hydrazyl, showed highly significant differences in the antioxidant activity of $C$. vulgaris under the effect of different concentrations of the tested vitamins being at range from 42.80 to $56.26 \%$ Ascorbic acid, 42.26 to $56.13 \%$ Riboflavin, 42.13 to $73.60 \%$ Thiamine, and 12.53 to $23.20 \%$ for Pyridoxal, Figure 2. The result shows the $C$. vulgaris blends with Pyridoxal gives lower antioxidant activities with all tested concentrations, and also in compared with the effect of other vitamins and concentrations. Meanwhile, the Thiamine concentrations 0.04 and $0.08 \mu \mathrm{g} / \mathrm{L}$ possessed higher antioxidants activity in compared to control.

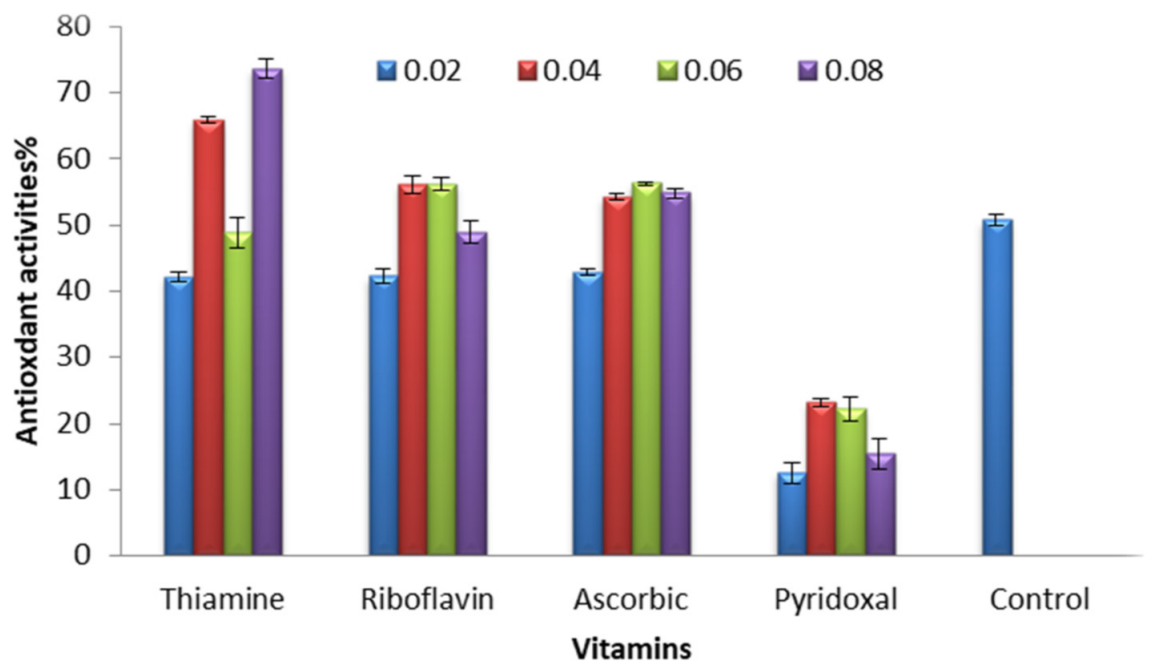

Figure 2. Effects of different concentrations of the tested vitamins supplementation on antioxidant activities of $C$. vulgaris as determined by DPPH (Antioxidant assay) 1,1-Diphenyl-2-picryl-hydrazyl. 
2.5. Antitumor Effect of C. vulgaris and C. vulgaris Supplemented with Different Concentrations of Thiamine (Vit. B1)

The effects of different concentrations of $C$. vulgaris and C. vulgaris blended with $0.08 \mu \mathrm{g} / \mathrm{mL}$ of Thiamine on the inhibition of various cancer cells were summarized in Table 6. Results revealed that methanol extracts of $C$. vulgaris and $C$. vulgaris supplemented with Thiamine at different concentrations $(100,200,400,600$ and $800 \mu \mathrm{g} / \mathrm{mL})$ affect inhibition of various cancer cells (HEPG-2, HCT-116, Hela and PC-3). However, C. vulgaris supplemented with Thiamine gives better results compared with $C$. vulgaris without Thiamine supplementation. The higher concentrations were most effective against cancer cells

Table 6. Percentage of relative inhibitions of various cancer cells (HEPG-2, HCT-116, Hela, and PC-3) that treated by different concentrations of methanol extracts of $\mathrm{C}$. vulgaris $(\mathrm{Chl})$ and $\mathrm{C}$. vulgaris supplemented with Thiamine (vitamin B1) (Chl + Thia). Human prostate cancer (PC-3), Hepatocellular carcinoma (HEPG-2), Colorectal carcinoma (HCT-116), and Epitheliod Carcinoma (Hela).

\begin{tabular}{ccccccccc}
\hline $\begin{array}{c}\text { Cancer Cell } \\
\text { Conc., } \boldsymbol{\mu g} / \mathbf{m L}\end{array}$ & Chl HePG-2 & Chl + Thia & Chl & Chl + Thia & Chl & Chl + Thia & Chl & Chl + Thia \\
\hline 100 & $71.2 \pm 4$ & $83.8 \pm 2$ & $68.9 \pm 6$ & $89.3 \pm 5$ & $80.1 \pm 9$ & $88.4 \pm 4$ & $64 \pm 4$ & $84.8 \pm 6$ \\
200 & $83.8 \pm 5$ & $89.5 \pm 5$ & $76.5 \pm 8$ & $93.8 \pm 4$ & $90.2 \pm$ & $90.7 \pm 9$ & $80.3 \pm 5$ & $91.3 \pm 4$ \\
400 & $90.9 \pm 9$ & $92.6 \pm 6$ & $87.7 \pm 4$ & $97.7 \pm 7$ & $95.5 \pm 3$ & $95 \pm 7$ & $88.8 \pm 4$ & $95.9 \pm 3$ \\
600 & $93.6 \pm 3$ & $96.4 \pm 4$ & $95.1 \pm 3$ & $98.2 \pm 8$ & $97.4 \pm 8$ & $97.8 \pm 4$ & $92.7 \pm 3$ & $96.9 \pm 7$ \\
800 & $95.7 \pm 6$ & $97.9 \pm 9$ & $97.6 \pm 5$ & $99 \pm 4$ & $98.1 \pm 4$ & $98.8 \pm 8$ & $94.4 \pm 3$ & $98.2 \pm 4$ \\
\hline
\end{tabular}

\subsection{FT-IR}

The FT-IR analyzes of C. vulgaris biomass (control) and blended with thiamin embodied various absorption peaks Figure 3. The peaks were, with C. vulgaris control 3404, 2970, 2925, $2856,1655,1549,1408,1384,1054,711$ and $568 \mathrm{~cm}^{-1}$ which has moved to $3449,2959,2954$, $2853,2768,1646,1384,1076,875,831,600$ and $564 \mathrm{~cm}^{-1}$. In comparison between results of C. vulgaris biomass (control) and blended with thiamin, bands $3404 \mathrm{~cm}^{-1}$ in C. vulgaris are moved to $3449 \mathrm{~cm}^{-1}$, the same site denoted the O-H stretching vibration $\left(3500-3200 \mathrm{~cm}^{-1}\right)$, that related to occurred of alcohols, phenols. The bands 2970 and 2925 changed to 2959 and 2923 in C. vulgaris (control), and C. vulgaris to blend with Thiamine. The peaks range from $3300-2500 \mathrm{~cm}^{-1}$ are representing $\mathrm{O}-\mathrm{H}$ stretching vibration occasion of carboxylic acids. The band 1655 was moved to 1646 and 1045 changed to 1076 . The band 2426 was showed only with C. vulgaris blended with Thiamine, and the two bands 1549 and 1048 were showed only with $C$. vulgaris (control), these results denoted the change in chemical structure of $C$. vulgaris blended with Thiamine. 


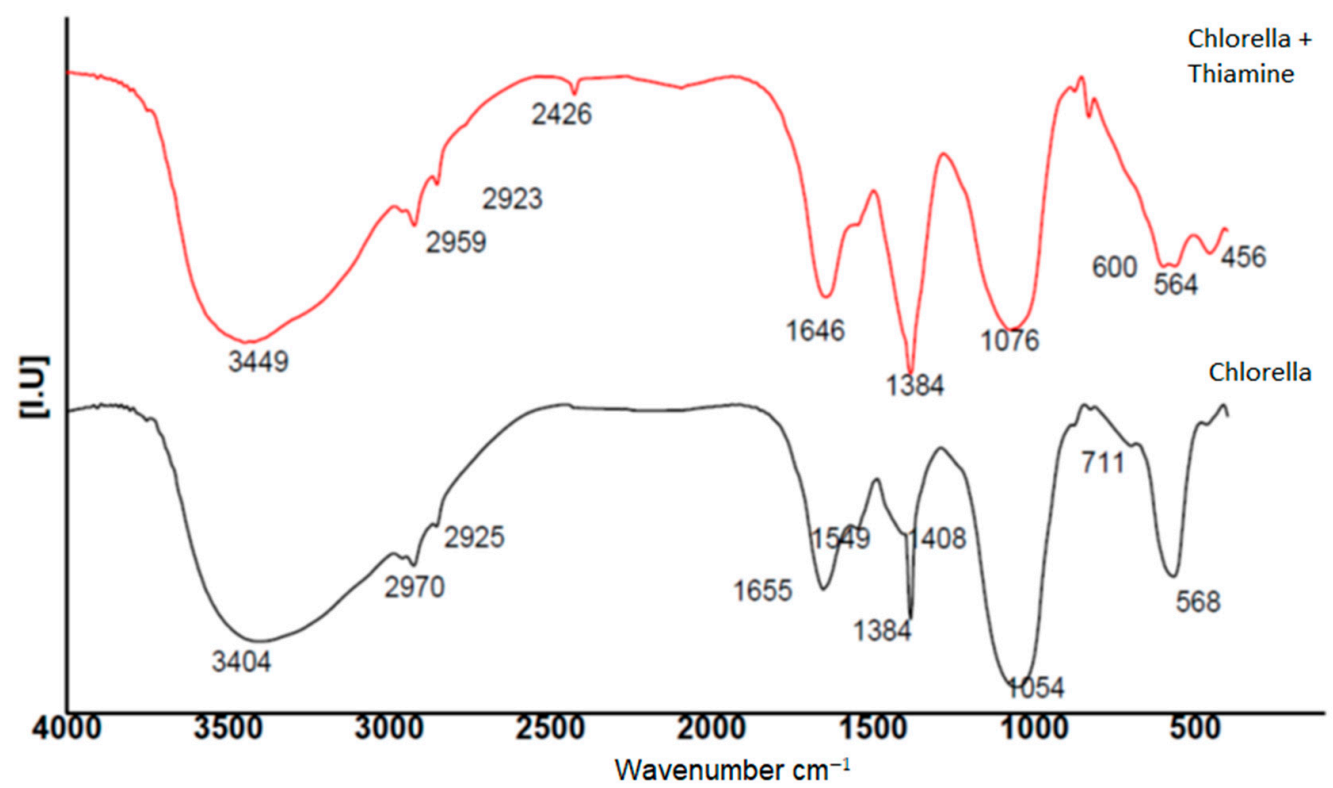

Figure 3. The FT-IR frequency range and the following functional groups are present in the C. vulgaris and with thiamine.

\section{Discussion}

Vitamins play vital roles in the development of the contents of microalgae [24]. Algae required various nutrients in addition to carbon dioxide, light, and water for growth Meanwhile, for faster growth, numerous microalgae require the supply of vitamins such as thiamine, biotin, or cobalamine because they cannot synthesize them $[25,26]$. Certain types of microalgae grow fast and efficiently in the presence of prokaryotes that produce vitamin $\mathrm{B}$ that is absorbed by microalgae [27]. Vitamins perform a vital role in the promotion of the primary productivity of the marine ecosystem and induction of microalgae bloom [28,29]. Vitamin B1 was the first cofactor that affects in microalgae growth and also plays a major role in carbohydrate and protein metabolism [30-32]. A large number of microalgae demand an external supply of thiamine [24]. Total chlorophyll- $a$ of Cyclotella nana increased with all concentrations of vitamin B12 [23]. Moreover, Menzel and Spaeth [33] reported that vitamins have a vital role in marine ecology not only in the capability to impact in yields but also in affecting in growth rate. When Cyclotella nana grew in different concentrations of vitamin B12, the cell numbers were little changed during the first 2 days, the best concentration of vitamin B12 was $3 \mathrm{ng}$ [23]. However, Algae were significantly increased when vitamins were found in the growth media [33]. Total chlorophyll- $a$ was elevated daily when Cyclotella nana grew at various concentrations of vitamin B12 but in Monochrysis lutheri, chlorophyll-a, elevated in the first 3 days of incubations [23]. Furthermore, Lwoff and Dusi [34] investigated that some cryptophyta demands vitamins such as thiamine as a growth factor. Menzel and Spaeth [33] showed that diatom blooms grow moderately when cobalamine was supplemented at the highest concentrations. In addition, several studies correlate algal yields and vitamin concentrations [35,36]. Harmful algal blooms were increased with vitamins concentration in water in a similar manner as amino acids and protein [37]. More than $70 \%$ of microalgae need supplementations of one or more vitamins [38]. Microgreen algae Volvox aureus and Pandorina morum required thiamine and vitamin B12, Desmidium swartzii required vitamin B12, Synura petersenii required vitamin $\mathrm{B} 12$, and biotin for growth $[38,39]$. Supplementation of $\mathrm{Chu} 10 \mathrm{D}$ medium with vitamins B1, B6, B7 and B12 produced higher biomasses of Chlorella vulgaris that were possibly used as feedstock for the productions of biofuels [40]. Vitamin B6 enhances the growth of Chaetoceros calcitrans [41]. The growth rate of Haematococcus was increased when the growth media were supplemented with $50 \mathrm{mg} / \mathrm{L}$ vitamin B12 [42]. Desouky [43] reported that the total carbohydrate contents of $C$. vulgaris were significantly elevated when supplemented 
with 200 ppm of riboflavin (vitamin B2). Vitamins are essential for the continued growth of some algae and also an adverse effect of some heavy metals [43-45]. Thiochrome (a natural metabolite of thiamine) can enhance the reproduction of Chlorella vulgaris [46]. Total carbohydrate content was significantly elevated when $200 \mathrm{ppm}$ of ascorbic (vitamin C) acid or thiamine (vitamin B1) were added for different levels of either $\mathrm{CoCl}_{2}$ or $\mathrm{NiCl}_{2}$ to Chlorella vulgaris [47]. The Chlorella vulgaris cell number, dry weight, total pigments content, and total carbohydrates were significantly increased when inoculated in different levels of $\mathrm{Pb}^{+2}$ and supplemented with $200 \mathrm{ppm}$ riboflavin [43]. Total carbohydrates and total proteins increased significantly when Chlamydomonas reinhardtii was supplemented with thiamine and different concentrations $(25,50$ and $75 \mathrm{mM})$ of $\mathrm{NaCl}$ [48]. The free amino acid contents of Scenedesmus obliquus were significantly increased when supplemented with $200 \mathrm{ppm}$ pyridoxine and riboflavin [49]. C. vulgaris supplemented with Thiamine is a potential source of natural antioxidants [50]. Chlorella vulgaris has antioxidant activities and anti-cholesterol [51]. The addition of Thiamine promoted the oxidative damage of $\mathrm{Cu}^{+2}$ on C. vulgaris growth and improved growth, pigment contents [52]. The antioxidant enzymes of Chlorella vulgaris were increased when exposed to UV-B [53]. The higher antioxidant activities were present in Chlorella methanolic extract [54]. Magnetic fields enhance the growth and antioxidant activities of Chlorella vulgaris [55]. Chlorella vulgaris has antioxidant and anticancer activities [56]. Hot water extract of Chlorella vulgaris decreased the number of viable HepG2 cells due to increased DNA damage and apoptosis [57]. Nanocellulose and the $\mathrm{Au} /$ cellulose nanocomposite derived from Chlorella vulgaris posses' significant cytotoxicity against lung cancer cells (A549) due to improve the relative expression of p53 gene, while reduced that of the Raf-1 gene [58]. In the FT-IR spectroscopy analysis of C. vulgaris biomass and supplemented with Thiamine there was the change in the peak position and also there were new peaks and disappear other peaks in the alga supplemented with thiamine, that denoted that modification of algal structure after treatments and hence effect in properties and metabolites [59]. Structural changes particular components were investigated using vibrational spectroscopy [60]. Fourier transform infrared (FTIR) spectra measured the change of macromolecular composition of Microcystis aeruginosa and Protoceratium reticulatum in response to the treatments [61].

\section{Materials and Methods}

\subsection{Tested Alga}

Chlorella vulgaris was attained from our lab (GEBRI), University of Sadat City, Egypt, and used as a test organism. The medium was BG11 (Table 7) nutritive culture for the enrichment and growing of the tested alga. Chlorella vulgaris culture subject (control) and four different vitamins concentration were supplemented to BG11 medium, Thiamine (B1), Riboflavin (B2), Pyridoxine $\left(\mathrm{B}_{6}\right)$, Ascorbic acid (c). Vitamin concentrations were adjusted to $0.02,0.04,0.06$ and $0.08 \mu \mathrm{g} / \mathrm{L}$. Two. Each vitamin was added to the culture media after the medium sterilization in autoclave and the vitamin sterilize by Millipore filter $45 \mu$ pore, due to the vitamins may be decompose high temperature in autoclave. The cultures were put at a west-facing window receiving natural daylight at a temperature $30 \pm 2{ }^{\circ} \mathrm{C}$ and shaken moderately thrice a day to prevent clumping. Culture growth was estimated by optical density at $660 \mathrm{~nm}$ by using Shanghai Unico UV-2000 spectrophotometer.

\subsection{Preparation of Algal Extracts}

Algal cultures, C. vulgaris, and C. vulgaris supplemented with different concentrations of the tested vitamins were put in the previously mentioned conditions. In a log phase, algal biomass was collected, washing and dried. Equal to one $\mathrm{g}$ of dried alga was mixed with $100 \mathrm{~mL}$ of methanol for $4 \mathrm{~h}$ in magnetic stirrer, after $4 \mathrm{~h}$ the algal mixture was filtrated through Whatman No.1 filter paper, and then dried by vacuum at $50{ }^{\circ} \mathrm{C}$ using a rotary evaporator. 
Table 7. BG11 medium contents.

\begin{tabular}{cccc}
\hline Constituent A & \multicolumn{3}{c}{ Constituent C } \\
\hline Stock solution & $\mathrm{g} / \mathrm{L}$ & Trace elements & $\mathrm{mg} / \mathrm{L}$ \\
$\mathrm{NaNO}_{3}$ & 1.5 & $\mathrm{H}_{3} \mathrm{BO}_{3}$ & 2.8 \\
$\mathrm{~K}_{2} \mathrm{HPO}_{4} \cdot 3 \mathrm{H}_{2} \mathrm{O}$ & 0.04 & $\mathrm{MnCl}_{2} \cdot 4 \mathrm{H}_{2} \mathrm{O}$ & 1.81 \\
$\mathrm{MgSO}_{4} \cdot 7 \mathrm{H}_{2} \mathrm{O}$ & 0.075 & $\mathrm{ZnSO}_{4} \cdot 7 \mathrm{H}_{2} \mathrm{O}$ & 0.222 \\
$\mathrm{CaCl}_{2} \cdot 2 \mathrm{H}_{2} \mathrm{O}$ & 0.036 & $\mathrm{Na} \cdot \mathrm{MoO}_{4} \cdot 2 \mathrm{H}_{2} \mathrm{O}$ & 0.39 \\
$\mathrm{Na}_{2} \mathrm{CO}_{3}$ & 0.02 & $\mathrm{CuSO}_{4} \cdot \mathrm{H}_{2} \mathrm{O}$ & 0.079 \\
Constituent B & & $\mathrm{Co}\left(\mathrm{NO}_{3}\right)_{2} \cdot 6 \mathrm{H}_{2} \mathrm{O}$ & 0.0494 \\
EDTA (disodium magnesium salt) & $0.001 \mathrm{~g} / \mathrm{L}$ & & \\
\hline
\end{tabular}

\subsection{Estimation of Pigments Content of C. vulgaris}

Five $\mathrm{mL}$ of homogenized $C$. vulgaris suspension were centrifuged for $10 \mathrm{~min}$ at $4000 \mathrm{rpm}$. The extractions of pigments were obtained by using $5 \mathrm{~mL} 90 \%$ acetone from the pellets. The tubes were placed in the dark for $24 \mathrm{~h}$. After that sample was centrifuged for $15 \mathrm{~min}$ at $5000 \mathrm{rpm}$ and the supernatant was collected. The absorbance was read at 662, 645 , and $470 \mathrm{~nm}$ (A662) against 90\% acetone as blank by using Shanghai Unico UV-2000 spectrophotometer. The calculation of pigments according to the following equations:

$$
\begin{gathered}
\text { Chlorophyll- } a\left(\mu \mathrm{g} \cdot \mathrm{mL}^{-1}\right)=11.75 \cdot \mathrm{A} 662-2.350 \cdot \mathrm{A} 645 \\
\text { Chlorophyll- } b\left(\mu \mathrm{g} \cdot \mathrm{mL}^{-1}\right)=18.61 \cdot \mathrm{A} 645-3.960 \cdot \mathrm{A} 662 \\
\text { Carotenoids }\left(\mu \mathrm{g} \cdot \mathrm{mL}^{-1}\right)=1000 \mathrm{~A} 470-2.270 \cdot \mathrm{Ca}-81.4 \mathrm{Cb} / 227
\end{gathered}
$$

\subsection{Determination of Protein and Carbohydrate Content of C. vulgaris}

Protein contents of $C$. vulgaris supplemented with various concentrations of the tested vitamins were determined using Folin phenol reagent according to the method adopted by Lowry et al. [62], carbohydrate contents were determined by the Anthrone method of Hedge and Hofreiter [63].

\subsection{Evaluation of the Antioxidant Activity of C. vulgaris In Vitro}

\subsubsection{DPPH Free Radicals Scavenging Assay}

The antioxidant activity of $C$. vulgaris extracts and $C$, vulgaris extracts supplemented with the tested vitamins at various concentrations $(0.02,0.04,0.06$, and $0.08 \mu \mathrm{g} / \mathrm{L})$ were tested by 2, 2,2-diphenyl-1-picrylhydrazyl (DPPH) test. One $\mathrm{ml}$ of $0.03 \mathrm{~g}$ DPPH in $50 \mathrm{~mL}$ methanol was mixed to $1 \mathrm{~mL}$ of methanol extract $C$. vulgaris culture subject (control), and along with four different vitamins concentration and incubated for $30 \mathrm{~min}$ at room temperature, the absorbance was measured at $517 \mathrm{~nm}$ by using Unico UV-2000 spectrophotometer. The antioxidant activity was calculated according to the following equation.

$$
\text { Antioxidant activities } \%=\left(\frac{\mathrm{B}-\mathrm{S}}{\mathrm{B}}\right) * 100
$$

(S) The absorbance of sample, (B) Absorbance of blank

4.5.2. Determination of the Antitumor Activities of C. vulgaris

\section{Cell Line}

Four human tumor cell lines namely; Human prostate cancer (PC-3), Hepatocellular carcinoma (HEPG-2), Colorectal carcinoma (HCT-116), and Epitheliod Carcinoma (Hela) were used. The cell lines were obtained from ATCC via Holding company for biological products and vaccines (VACSERA), Cairo, Egypt. 


\section{Chemical Reagents}

The RPMI-1640 medium, MTT and DMSO (sigma co., St. Louis, MI, USA), Fetal Bovine serum (GIBCO, Cramlington, UK) were used.

\section{MTT Assay}

The cell lines declared above were used to investigate the suppression effects of methanol extracts of $C$. vulgaris and C. vulgaris blended with $0.08 \mu \mathrm{g} / \mathrm{L}$ of thiamine on cell growth using the MTT assay $[64,65]$. (The methanol extracts of $C$. vulgaris and $C$. vulgaris blended with $0.08 \mu \mathrm{g} / \mathrm{L}$ of thiamine were evaporated by Rotary evaporator, followed by dissolved in Dimethyl sulfoxide (DMSO), to prepare the following concentration (100, 200, 400,600 , and $800 \mu \mathrm{g} / \mathrm{mL}$ ). The colorimetric assay is measured at absorbance of $570 \mathrm{~nm}$ using a plate reader (EXL 800, New York, NY, USA). The relative cell viability in percentage was calculated as (A570 of treated samples/A570 of untreated sample) $\times 100$.

\subsection{FT-IR Analysis}

Fourier transform infrared (FTIR) spectroscopy was used to estimate the presences and change of the functional groups in C. vulgaris and C. vulgaris blended with Thiamine [66].

\subsection{Statistical Analysis}

Fixed effects included vitamin concentrate, pigment, and time were investigated according to Proc ANOVA using a statistical analysis system (SAS, 2012), and a $p$-value of $\leq 0.05$ was considered to indicate statistical significance. The differences between means were detected by Duncan's Multiple Range Test [67].

\section{Conclusions}

C. vulgaris has applications in food, antibiotics, pharmaceutical compounds and is also used in biofuels such as biodiesel and bioethanol. In this work, we have tested the effects of adding various vitamins at different concentrations to $C$. vulgaris growth media on the $C$. vulgaris growth criteria (Optical density, total photosynthetic pigments, antioxidant (DPPH) activity and total protein, carbohydrate contents) during 18 days of cultivation compared with control C. vulgaris (without vitamins supplementations). The results confirmed that all the supplemented vitamins have a significant effect on alga growth (increasing C. vulgaris biomass) and the best vitamin was thiamine at a concentration of $0.08 \mu \mathrm{g} / \mathrm{L}$. In addition, C. vulgaris without and with thiamine have anticancer properties when tested in vitro however, $C$. vulgaris supplemented with thiamine was more effective.

Author Contributions: R.A.H. Conceptualization, methodology, and writing original draft preparation, A.A.E.L. Conceptualization, methodology, and writing original draft preparation E.M.E. methodology, and formal Analysis, A.S.A. visualization and added resources, A.M.A. visualization and added resources H.A.H. conceptualization, and supervision. All authors have read and agreed to the published version of the manuscript.

Funding: This research received no external funding.

Institutional Review Board Statement: Not applicable.

Informed Consent Statement: Not applicable.

Data Availability Statement: Not applicable.

Conflicts of Interest: The authors declare that they have no known competing interest.

Sample Availability: Samples of the compounds are available by authors. 


\section{References}

1. Wang, H.; Oo Khor, T.; Shu, L.; Su, Z.Y.; Fuentes, F.; Lee, J.H.; Tony Kong, A.N. Plants vs. cancer: A review on natural phytochemicals in preventing and treating cancers and their drug ability. Anti-Cancer Agents Med. Chem. 2012, 12, $1281-1305$. [CrossRef]

2. Ye, H.; Wang, K.; Zhou, C.; Liu, J.; Zeng, X. Purification, antitumor and antioxidant activities in vitro of polysaccharides from the brown seaweed Sargassum pallidum. Food Chem. 2008, 111, 428-432. [CrossRef] [PubMed]

3. Fan, X.; Bai, L.; Zhu, L.; Yang, L.; Zhang, X. Marine algae-derived bioactive peptides for human nutrition and health. J. Agric. Food Chem. 2014, 62, 9211-9222. [CrossRef] [PubMed]

4. Guil-Guerrero, J.L.; Navarro-Juárez, R.; López-Martınez, J.C.; Campra-Madrid, P.; Rebolloso-Fuentes, M. Functional properties of the biomass of three microalgal species. J. Food Eng. 2004, 65, 511-517. [CrossRef]

5. Kuda, T.; Kunii, T.; Goto, H.; Suzuki, T.; Yano, T. Changes of radical-scavenging capacity and ferrous reducing power in chub mackerel Scomber japonicus and Pacific saury Cololabissaira during $4{ }^{\circ} \mathrm{C}$ storage and retorting. Food. Chem. 2007, 5, 103-900.

6. Fedorov, S.N.; Ermakova, S.P.; Zvyagintseva, T.N.; Stonik, V.A. Anticancer and cancer preventive properties of marine polysaccharides: Some results and prospects. Mar. Drugs 2013, 11, 4876-4901. [CrossRef]

7. Specht, E.; Miyake-Stoner, S.; Mayfield, S. Micro-algae come of age as a platform for recombinant protein production. Biotechnol. Lett. 2010, 32, 1373-1383. [CrossRef]

8. Sarkar, A.; Ghosh, U. Natural antioxidants-The key to safe and sustainable life. Int. J. Latest Trends Eng. Technol. 2016, 6, 460-466.

9. Munir, N.; Sharif, N.; Naz, S.; Manzoor, F. Algae: A potent antioxidant source. Sky J. Microbiol. Res. 2013, 1, $22-31$.

10. Nick, G.L. Addressing human exposure to environmental toxins with Chlorella pyrenoidosa-Medicinal properties in whole foods. Town Send Lett. Dr. Patients 2003, 237, 28-32.

11. Yaakob, Z.; Ali, E.; Zainal, A.; Mohamad, M.; Takriff, M.S. An overview: Biomolecules from microalgae for animal feed and aquaculture. J. Biol. Res.-Thessalon. 2014, 21, 6-15. [CrossRef] [PubMed]

12. Cai, X.; Yang, Q.; Wang, S. Antioxidant and hepatoprotective effects of a pigment-protein complex from Chlorella vulgaris on carbon tetrachloride-induced liver damage in vivo. RSC Adv. 2015, 5, 96097-96104. [CrossRef]

13. Morris, H.J.; Almarals, A.; Carrill, O.; Bermudez, R.C. Utilisation of Chlorella vulgaris cell biomass for the production of enzymatic protein hydrolysates. Bioresour. Technol. 2008, 99, 7723-7729. [CrossRef] [PubMed]

14. Pulz, O.; Groo, W. Valuable products from biotechnology of microalgae. Appl. Microbiol. Biot. 2004, 65, 635-648. [CrossRef] [PubMed]

15. Baianova, I.; Trubachev, I.N. Comparative evaluation of the vitamin composition of unicellular algae and higher plants grown under artificial conditions. Prikl. Biokhim. Mikrobiol. 1981, 17, 400-407. [PubMed]

16. Fujiwara, Y. Effect of long term administration of Chlorella tablets on hyperlipemia. Nippon Eiyo Shokuryo Gakkaishi 1990, 43, 167-173. [CrossRef]

17. Hasegawa, T.; Noda, K.; Kumamoto, S.; Ando, Y.; Yamada, A.; Yoshikai, Y. Chlorella vulgaris culture supernatant (CVS) reduces psychological stress induced apoptosis in thymocytes of mice. Int. J. Immunopharmacol. 2000, 22, 877-885. [CrossRef]

18. Reddy, C.M.; Bhat, V.B.; Kiranmai, G.; Reddy, M.N.; Reddanna, P.; Madyastha, K.M. Selective inhibition of cyclooxygenase-2 by Cphycocyanin, a biliprotein from Spirulina platensis. Biochem. Biophys. Res. Commun. 2000, 277, 599-603. [CrossRef]

19. Khan, Z.; Bhadouria, P.; Bisen, P.S. Nutritional and therapeutic potential of Spirulina. Curr. Pharm. Biotechnol. 2005, 6, 373-379. [CrossRef]

20. Basha, O.M.; Hafez, R.A.; El-Ayouty, Y.M.; Mahrous, K.F.; Bareedy, M.H.; Salama, A.M. C-Phycocyanin inhibits cell proliferation and may induce apoptosis in human HepG2 cells. Egypt J. Immunol. 2008, 15, 161-167.

21. Sheih, I.C.; Fang, T.J.; Wu, T.K. Isolation and characterization of a novel angiotensin I-converting enzyme (ACE) inhibitory peptide from the algae protein waste. Food Chem. 2009, 115, 279-284. [CrossRef]

22. Cruz-López, R.; Maske, H. The vitamin B1 and B12 required by the marine dinoflagellate Lingulodinium polyedrum can be provided by its associated bacterial community in culture. Front. Microbiol. 2016, 7, 560. [CrossRef] [PubMed]

23. Carlucci, F.; Silbernagel, S.B. Effect of vitamin concentrations on growth and development of vitamin-requiring algae. J. Phycol. 1969, 5, 64-67. [CrossRef]

24. Gobler, C.J.; Norman, C.; Panzeca, C.; Taylor, G.T.; Sanudo-Wilhelmy, S.A. Effect of B-vitamins (B-1, B-12) and inorganic nutrients on algal bloom dynamics in a coastal ecosystem. Aquat. Microb. Ecol. 2007, 49, 181-194. [CrossRef]

25. Tandon, P.; Jin, Q.; Huang, L. A promising approach to enhance microalgae productivity by exogenous supply of vitamins. Microb. Cell Factories 2017, 16, 219. [CrossRef]

26. Hannon, M.; Gimpel, J.; Tran, M.; Rasala, B.; Mayfield, S. Biofuels from algae: Challenges and potential. Biofuels 2010, 1, 763-784. [CrossRef]

27. Helliwell, K.E.; Scaife, M.A.; Sasso, S.; Araujo, A.P.U.; Purton, S.; Smith, A.G. Unraveling vitamin B-12-responsive gene regulation in algae. Plant Physiol. 2014, 165, 388-397. [CrossRef]

28. Kirrolia, A.; Bishnoi, N.R.; Singh, R. Response surface methodology as a decision-making tool for optimization of culture conditions of green microalgae Chlorella spp. for biodiesel production. Ann. Microbiol. 2014, 64, 1133-1147. [CrossRef]

29. Sylvander, P.; Häubner, N.; Snoeijs, P. The thiamine content of phytoplankton cells is affected by abiotic stress and growth rate. Microb. Ecol. 2013, 65, 566-577. [CrossRef] 
30. Monteverde, D.R.; Gómez-Consarnau, L.; Cutter, L.; Chong, L.; Berelson, W.; Sañudo-Wilhelmy, S.A. Vitamin B1 in marine sediments: Pore water concentration gradient drives benthic flux with potential biological implications. Front Microbiol. 2015, 6, 434. [CrossRef] [PubMed]

31. Panzeca, C.; Tovar-Sanchez, A.; Agustí, S.; Reche, I.; Duarte, C.M.; Taylor, G.T.; Sañudo-Wilhelmy, S.A. B vitamins as regulators of phytoplankton dynamics. Eos Trans. Am. Geophys. Union 2006, 87, 593-596. [CrossRef]

32. Croft, M.T.; Warren, M.J.; Smith, A.G. Algae need their vitamins. Eukaryot Cell 2006, 5, 1175-1183. [CrossRef] [PubMed]

33. Menzel, D.W.; Spaeth, J.P. Occurrence of vitamin B12 in the Sargasso Sea. Limnol. Oceanogr. 1962, 7, 151-154. [CrossRef]

34. Lwoff, L.; Dusi, A.H. Le thiazol, facteur de croissance pour le flagella Polytoma ocellatum. CR Acad. Sci. 1937, $205,205-882$.

35. Sanudo-Wilhelmy, S.A.; Gobler, C.J.; Okbamichael, M.; Taylor, G.T. Regulation of phytoplankton dynamics by vitamin B12. Geophys. Res. Lett. 2006, 33, L04604. [CrossRef]

36. Vishniac, H.S.; Riley, G.A. Cobalamin and thiamine in Long Island Sound: Patterns of distribution and ecological significance. Limnol. Oceanogr. 1961, 6, 36-41. [CrossRef]

37. Tang, Y.Z.; Koch, F.; Gobler, C.J. Most harmful algal bloom species are vitamin B1 and B12 auxotrophs. Proc. Natl. Acad. Sci. USA 2010, 107, 20756-20761. [CrossRef]

38. Provasoli, L. Algal nutrition and eutrophication. In Eutrophication: Causes, Consequences, Correctives; Rohlich, G.A., Ed.; National Academies Press: Washington, DC, USA, 1969; pp. 574-593.

39. Pringsheim, E.G.; Pringsheim, O. Die Ernährung koloniebildender Volvocales. Biol. Zbl. 1959, 78, $937-971$.

40. Tarin, N.J.; Ali, N.M.; Chamon, A.S.; Mondol, M.N.; Rahman, M.M.; Aziz, A. Optimizing Chlorella Vulgaris and Anabaena Variabilis Growth Conditions for Use as Biofuel. Feed. Stock. J. Asiat. Soc. Bangladesh Sci. 2016, 42, 191-200. [CrossRef]

41. Krichnavaruk, S.; Loataweesup, W.; Powtongsook, S.; Pavasant, P. Optimal Growth Conditions and the Cultivation of Chaetoceros calcitrans in Airlift Photobioreactor. Chem. Eng. J. 2005, 105, 91-98. [CrossRef]

42. Li, L. Effect of vitamin-B12 and vitamin-H on the growth and astaxanthin content of Haematococcus pluvialis CH-1. Adv. J. Food Sci. Technol. 2013, 5, 1139-1142. [CrossRef]

43. Desouky, S.A. Alleviation the toxicity effect of lead acetate by riboflavin on growth parameters, photosynthesis, respiration, carbohydrates, proteins, free amino acids and proline of Chlorella vulgaris Beijer cultures. Al-Azhar Bull. Sci. 2003, 25-27, 277-279.

44. Berland, B.R.; Bonin, D.J.; Fiala, M.; Mastering, S.Y. Water and salt stress, kinetin and protein synthesis in tobacco leaves. Plant Physiol. 1978, 42, 361-365.

45. Swift, D.G. Vitamins and phytoplankton growth. In The Physiological Ecology of Phytoplankton Morris; Oxford: London, UK, 1980; Volume 6, pp. 239-368.

46. Petrov, S.A.; Zamorov, V.V.; Ustyanskaya, O.V.; Budnyak, O.K.; Chernadchuk, S.S.; Andrievskiy, O.M.; Kravchuk, I.O. Administration of Thiamine and Thiochrome Enhanced Reproduction of Chlorella, Drosophila melanogaster, and Danio. J. Nutr. Sci. Vitaminol. 1980, 62, 6-11. [CrossRef]

47. Desouky, S.A. Effect of Some Natural Organic Additives on the Growth and Photosynthesis of Pollutant-Chlorella Vulgaris Beijer. J. Appl. Sci. Res. 2011, 7, 23-32.

48. Moulin, M.; Nguyen, G.T.; Scaife, M.A.; Smith, A.G.; Fitzpatrick, T.B. Analysis of Chlamydomonas thiamin metabolism in vivo reveals riboswitch plasticity. Proc. Natl. Acad. Sci. USA 2013, 110, 14622-14627. [CrossRef] [PubMed]

49. Desouky, S.A. Response of vitamins on the growth criteria and some metabolic activities of stressed Scenedesmus obliquus cultures. Aust. J. Basic Appl. Sci. 2011, 5, 89-99.

50. Abd El Latif, A.; Assar, D.H.; Elkaw, E.M.; Hamza, H.A.; Alkhalifah, D.H.M.; Hozzein, W.N.; Hamouda, R.A. Protective role of Chlorella vulgaris with Thiamine against Paracetamol induced toxic effects on haematological, biochemical, oxidative stress parameters and histopathological changes in Wistar rats. Sci. Rep. 2021, 11, 3911.

51. Ibrahim, M.R.; Hamouda, R.A.; Tayel, A.A.; Al-Saman, M.A. Anti-cholesterol and Antioxidant Activities of Independent and Combined Microalgae Aqueous Extracts In Vitro. Waste Biomass Valorization 2021, 12, 4845-4857. [CrossRef]

52. Farghl, A.A. Thiamine and pyridoxine alleviate oxidative damage by copper stress in green alga Chlorella vulgaris. Egypt J. Microbiol. 2012, 47, 97-110.

53. Malanga, G.; Puntarulo, S. Oxidative stress and antioxidant content in Chlorella vulgaris after exposure to ultraviolet-B radiation. Physiol. Plant. 1995, 94, 672-679. [CrossRef]

54. Miranda, M.S.; Sato, S.; Mancini-Filho, J. Antioxidant activity of the microalga Chlorella vulgaris cultured on special conditions. Boll. Chim. Farm. 2001, 140, 165-168.

55. Wang, H.Y.; Zeng, X.B.; Guo, S.Y.; Li, Z.T. Effects of magnetic field on the antioxidant defense system of recirculation-cultured Chlorella vulgaris. Bioelectromagn. J. Bioelectromagn. Society. Soc. Phys. Regul. Biol. Med. Eur. Bioelectromagn. Assoc. 2008, $29,39-46$. [CrossRef]

56. El-Fayoumy, E.A.; Shanab, S.M.M.; Gaballa, H.S.; Tantawy, M.A.; Shalaby, E.A. Evaluation of antioxidant and anticancer activity of crude extract and different fractions of Chlorella vulgaris axenic culture grown under various concentrations of copper ions. BMC Complement. Med. Ther. 2021, 21, 51. [CrossRef]

57. Yusof, Y.A.M.; Saad, S.M.; Makpol, S.; Shamaan, N.A.; Ngah, W.Z.W. Hot water extract of Chlorella vulgaris induced DNA damage and apoptosis. Clinics 2010, 65, 1371-1377. [CrossRef]

58. Hamouda, R.A.; Abd El Maksoud, A.I.; Wageed, M.; Alotaibi, A.S.; Elebeedy, D.; Khalil, H.; Abdella, A. Characterization and Anticancer Activity of Biosynthesized Au/Cellulose Nanocomposite from Chlorella vulgaris. Polymers 2021, 13, 3340. [CrossRef] 
59. Bramanti, E.; Benedetti, E. Determination of the secondary structure of isomeric forms of human serum albumin by a particular frequency deconvolution procedure applied to Fourier transform IR analysis. Biopolymers 1996, 38, 639-653. [CrossRef]

60. Wetzel, R.; Becker, M.; Behlke, J.; Billwitz, H.; Bohn, S.; Ebert, B.; Hamann, H.; Krumbiegel, J.; Lassmann, G. Temperature behaviour of human serum albumin. Eur. J. Biochem. 1980, 104, 469-478. [CrossRef]

61. Jebsen, C.; Norici, A.; Wagner, H.; Palmucci, M.; Giordano, M.; Wilhelm, C. FTIR spectra of algal species can be used as physiological fingerprints to assess their actual growth potential. Physiol. Plant. 2012, 146, 427-438. [CrossRef]

62. Lowry, H.; Rosebrough, N.J.; Farr, A.L.; Randall, R. Protein determination by a modified Folin phenol method. J. Biol. Chem. 1951, 193, 265-275. [CrossRef]

63. Hedge, J.E.; Hofreiter, B.T. Carbohydrate Chemistry 17; Whistler, R.L., Be Miller, J.N., Eds.; Academic Press: New York, NY, USA, 1962.

64. Mosmann, T. Rapid colorimetric assay for cellular growth and survival: Application to proliferation and cytotoxicity assays. J. Immunol. Methods 1983, 65, 55-63. [CrossRef]

65. Denizot, F.; Lang, R. Rapid colorimetric assay for cell growth and survival: Modifications to the tetrazolium dye procedure giving improved sensitivity and reliability. J. Immunol. Methods 1986, 89, 271-277. [CrossRef]

66. Theivandran, G.; Ibrahim, S.M.; Murugan, M. Fourier Transform Infrared (Ft-Ir) Spectroscopic Analysis of Spirulina fusiformis. J. Med. Plants Stud. 2015, 3, 30-32.

67. Duncan, D.B. Multiple range and multiple F-test. In Biometrics; SAS Institute Inc.: Cary, NC, USA, 1955; Volume 11, pp. 1-42. 